International Journal of Applied Chemistry.

ISSN 0973-1792 Volume 13, Number 3 (2017) pp. 707-720

(C) Research India Publications

http://www.ripublication.com

\title{
Study Biodegradation of Aromatics Pyrene Using Bacterial Isolates from the Sea and micro symbionts Sponges
}

\author{
Ismail Marzuki ${ }^{1 *}$, Hadija Enryani Ismail ${ }^{2}$, Nursiah La Nafie ${ }^{3}$ and Seniwati Dali ${ }^{4}$ \\ ${ }^{1}$ Basic Laboratory of Chemical Engineering, Faculty of Engineering, University of \\ Fajar, Indonesia \\ ${ }^{2,3}$ Laboratory of Analytical Chemistry, Department of Chemistry, Faculty of \\ Mathematics and Natural Sciences, University of Hasanuddin, Indonesia \\ ${ }^{4}$ Biochemistry Laboratory, Department of Chemistry, Faculty of Mathematics and \\ Natural Sciences, University of Hasanuddin, Indonesia.
}

Correspondint author's email: ismailmz@unifa.ac.id; cc ismailmz3773@gmail.com

\begin{abstract}
Investigation of PAHs reshuffle by microorganisms has been done, but using sponge symbionts for the purpose of reduction of PAHs toxicity into simple organic compounds is still small. Microorganisms and sponges are known as complex animals that have various functions including the ability to produce bioactive compounds that can interact with hydrocarbon compounds as carbon sources. The purpose of this experiment was the use of bacteria isolated from seawater and sponges to reduce pyrene by biodegradation method by interacting between bacteria Alcaligenes faecalis strain Cu4-1 (AF), Bacillus subtilis strain BAB-1684 (BS) and Bacillus Cereus strain MER-8 (BC) capable of producing enzymes to overhaul the pyrene structure acting as a substrate. Biodegradation was carried out for 25 days, every 5 days to check degradation media using spectrophotometer and GC-MS to analyze degradation parameters: (1) optical density, (2) component abundance, (3) concentration and degradation rate of pyrene, and (4) ) Degraded organic of components. The results of the analysis of each degradation parameter were concluded: isolates, AF, BS and BC were able to degrade pyrene compounds, biodegradation rate: $\mathrm{AF}(97,65 \%)>\mathrm{BC}(95$, $27 \%)>\mathrm{BS}(93,15 \%)$. Marine-filled bacteria (AF and $\mathrm{BC}$ ) have a relatively
\end{abstract}


higher pyrene degradation ability than the BS microsimbiont isolated on Callyspongi sp. Biodegradation of organic components results isolates $\mathrm{AF}$ and $\mathrm{BC}$ is different from the organic component isolates BS biodegradation results indicate that there is a specific mechanism which is owned by each type of bacteria to degrade PAHs.

Keywords: Biodegradation, Sponge, microorganisms, Aromatic, hydrocarbons, GC-MS

\section{INTRODUCTION}

The existence of aromatic hydrocarbons in the environment is of considerable concern to the people and is well founded because the toxic properties of these compounds are very high, at risk to all living things. The carcinogenic and mutagenic properties of some PAH groups, especially the structure of three rings upwards, threaten the survival of human life. Diseases that can be caused by contaminants and exposure to aromatic hydrocarbon compounds are cancer in humans. The contamination of aromatic compounds in the free environment can not be avoided, can come from many sources, for example; Waste petroleum processing activities, oil spills or tanker transfortation ballasts, agricultural activities as insecticides, activity in certain chemical and industrial laboratories as well as the natural result of unintentional chemical reactions also potentially produce certain aromatic compounds. The presence of aromatic compounds in the environment both the area of contamination and volume, tend to be uncontrolled, resulting in negative impacts on environmental ecosystems higher and resistance to human health tends to rise due to the ability of aromatic compounds to cycle, ${ }^{[1,2,3]}$

Control and prevention of aromatics contamination of the environment into the needs can not be avoided. Some methods of controlling the contamination of aromatic compounds have been done, such as physics, chemical and biological methods, but less efficient and effective and costly, so an alternative method is needed to solve the problem. Deactivation of toxic substances aromatics using natural materials, for example the use of microorganisms as biomaterials degradation of contamination of aromatic components is the main choice by experts in their field. Some indegenous and endogenous bacteria have been shown to degrade the hydrocarbon aliphatic components and some aromatic components. Bacteria such as Bacillus sp, Bacillus macerans, Bacillus mycoides, Bacillus megaterium, Bacillus subtilis, Pseudomonas sp., Citrobacter sp., and Paracoccus sp., ${ }^{[3,4,5,6,7,8]}$

Sources of bacteria that is often used as a biomaterial degrading hydrocarbon compounds can be isolated from various sources, such as some species mangrov, sponges species, types of mold, water areas, as well as the hydrocarbon contaminated soil at the shelter hydrocarbon waste, ${ }^{[6,7,8,9,10,11,12]}$. Degradation method using several types of bacteria is believed to be more effective and efficient than other methods, but 
found a number of problems and weaknesses in the application of unpredictable, such as: bacterial regeneration, bacterial population used, bacteria, ideal bacterial concentration, degradation mechanism of a bacteria to the type The aromatic components, the concentration of aromatic wastes, the type of aromatic components, so that various methods of application including the use of catalysts to solve the problem, ${ }^{[13,14,15]}$. A deeper assessment of the degradation of hydrocarbon aromatic poly (PAH) components using very wide and complex microorganisms to be carried out with several possible studies, such as application methods, microorganism types, bacterial isolate sources, needs and types of suitable catalysts, nutrients and bacterial working mechanisms components degrade PAHs, ${ }^{[15,16,17,18]}$

\section{MATERIALS AND METHODS}

\subsection{Material}

Materials used: Three types of bacterial isolates, namely: Alcaligenes faecalis strain Cu4-1 [AF], Bacillus subtilis strain BAB-1684 [BS], and Bacillus Cereus strain MER-8 [BC]. With an average bacterial cell count of $4,8.10^{3}$ cells / $\mathrm{mL}$, a solution of Salt Minerals Stone Solution (SMSS), Nutrient Agar (NA), Pyrene (sigma), Methanol pa, $\mathrm{HCl}, \mathrm{NaCl} 0.9 \%$ physiological, pure culture of Pseudomonas bacteria Sp, n-hexane pa, $\mathrm{Na}_{2} \mathrm{SO}_{4}$ anhydrous pa, iso-octane [CA540-84-1], dichloromethan GR [Brand, ${ }^{[3,4,7]}$

Tools consist: (1) GC-MS [Agilent 7890], the operating conditions for GC-MS (maximum temperature $350{ }^{\circ} \mathrm{C}$, the increase in temperature of $10{ }^{\circ} \mathrm{C}$, every 5 minutes, pressure $18.406 \mathrm{psi}$, a Helium gas carrier, a speed of $150 \mathrm{~mL} / \mathrm{min}$, capillary column [Agilent 19019S-436HP-5 ms], dimensions of $60 \mathrm{mx} 250 \mu \mathrm{m} \times 0.25 \mu \mathrm{m}$, the pressure $18,406 \mathrm{psi}$, separation $26,128 \mathrm{~cm} / \mathrm{sec}$, A retention time of maximum 30 minutes), (2 ) Spectronic 20 D* [Thermo E. Corp]. Wavelength of $600 \mathrm{~nm}$, (3) centrifugation set [DKC-1006T] 6 tube, (4) blender [Philips AE105], (5) filter of $0.2 \mu \mathrm{m}$ [millex-LH], (6) incubator shaker [Enviro-Genie] , (7) micro pipette [Dragon Onemed], (8) set sheet analytic [Mettler PM-200], (9) spoit, (10) Universal pH paper Brands, and (11) PCR.

\subsection{Method}

1. Preparation suspension of isolates and determination cell numbers of bacterial colonies

Determination the number of colony cells: begins by making suspension of Alcaligenes faecalis strain $\mathrm{Cu} 4-1(\mathrm{AF})$. Entering $\pm 2 \mathrm{~mL}$ of $0.9 \%$ physiological $\mathrm{NaCl}$ solution into the reaction tube containing AF isolates, after all the soluble AF colonies, obtained a concentrated AF suspension, diluted the ratio of $1 \mathrm{~mL}$ of suspension in $500 \mathrm{~mL} 0.9 \%$ physiological, $0.45 \% \mathrm{NaCl}$. The AF suspension is cultured in a Petri dish containing Marine Agar (MA) medium and incubated for 2 x 24 hours. The number of AF colonies 
was calculated using the formula: The formula $\mathrm{N}=\Sigma \mathrm{C} /(\mathrm{V} \times 1,1 \times \mathrm{d})$. The number of colonies of $\mathrm{BS}$ and $\mathrm{BC}$ is determined by the same method as the determination of the number of colonies of AF cells, ${ }^{[3.15,20]}$

\section{Pyrene $100 \mathrm{mg} / \mathrm{L}$}

Dissolving $0.025 \mathrm{~g}$ of pyrene with $25 \mathrm{~mL}$ dichloromethane, obtained $1000 \mathrm{mg} / \mathrm{L}$ concentration of pyrene, then $10 \mathrm{~mL}$ dipipet into 100 pistachio squeezed with dichloromethan obtained $100 \mathrm{mg} / \mathrm{L}$ pyrene.

\section{Pyrene biodegradation using bacterial suspension based on contact time}

Five Erlenmeyer $50 \mathrm{~mL}$, each filled with MA medium and $100 \mathrm{mg} / \mathrm{L}$ pherent substrate, 1: 1 ratio, homogenized using a magnetic stirrer. The media was sterilized for 15 minutes, and $5 \mathrm{~mL}$ of $\mathrm{AF}$ isolates were added to contact with the pyrene (degradation process), and incubated for 24 hours at $37{ }^{\circ} \mathrm{C}$, at shakers at $150 \mathrm{rpm}$. Each bacterial medium was piped $10 \mathrm{~mL}$ into a new medium, homogenized and incubated at $37^{\circ} \mathrm{C}$. Sampling suspension is done every 5 days. Each AF sample obtained in the incubation for 24 hours. Contact time for 25 days, ${ }^{[5,13,14]}$. The same method was performed on BS and $\mathrm{BC}$ isolates.

\section{Determination of Pyrene concentration of residual degradation}

AF degradation media samples were drawn as much as $5 \mathrm{~mL}$, each added $5 \mathrm{~mL}$ dichloromethane, extracted using ultrasonic. Taken organic phase, plus anhydrous sodium sulfate to remove water content. The organic phase was concentrated with nitrogen gas up to the final volume $\pm 5 \mathrm{~mL}$, then the AF sample analysis using GC-MS. The same way, done on BS and BC samples, ${ }^{[5,7,12,14]}$

\section{Parameter Analysis}

Parameters analyzed as a reference for determining whether the three bacterial isolates used can degrade pyrene, ie: (1) optical density, (2) retention time to pyrene abundance, (3) pyrene concentration on contact time and (4) identification of degradation component, ${ }^{[5,13,14]}$

\section{RESULTS AND DISCUSSION}

\subsection{Optical Density (DO)}

One indicator of bacterial isolation degradation process against aromatic components 
can be seen in optical density of degradation media. The degradation that occurs is seen as the mechanism of the enzymatic reaction. The aromatic compounds are positioned as substrate while bacterial isolates are microorganisms that produce enzymes because the survival of bacteria is threatened by the toxic properties of aromatic compounds, ${ }^{[5,19,20]}$. The value of optical density up or down at certain contact times describes the situation of bacterial threats to the habitat in which the bacteria live. Table 1 below shows the presence of bacterial degradation processes against the pyrene.

Table 1. Suspension Optical Density Based on Contact Day

\begin{tabular}{lllllll}
\hline \multirow{2}{*}{ Sample } & \multicolumn{7}{c}{ Optical density based on contact time (days) } & \\
& 0 days & $\mathbf{5}$ days & $\mathbf{1 0}$ days & $\mathbf{1 5}$ days & $\mathbf{2 0}$ days & $\begin{array}{l}\text { days } \\
\text { day }\end{array}$ \\
\hline AF & 0.043 & 0.671 & 0.772 & 0.469 & 0.386 & 0.303 \\
BS & 0.035 & 0.476 & 0.545 & 0.512 & 0.369 & 0.332 \\
BC & 0.037 & 0.778 & 0.814 & 0.567 & 0.295 & 0.210 \\
Control (-) & 0.015 & 0.045 & 0.039 & 0.046 & 0.057 & 0.067 \\
\hline
\end{tabular}

The optical density value profile of the spectrophotometer measurement results, (Table 1 ), shows that there is a process occurring in the degradation medium. Components of degradation media consist of pyrene, bacterial isolate and growth medium. The concentration of pyrene is constant $100 \mathrm{mg} / \mathrm{L}$, growth medium is fixed, while bacterial isolate type used consist of 3 (three) type with code of AF, BS and BC. Increased optical density values occurred at 5 days to 10 days on all three bacterial isolates, but at day 15 contact, day 20 to day 25, there was a significant decrease in optical density values. Media optical density pluctuations indicate that the three types of bacterial isolates used work in such a way as to adapt to the habitat in order to survive, although the degree of change in optical density varies in different bacterial isolates Differences in changes in optical density values indicate the type of bacteria's performance against the presence of threatening pyrene. Decrease in optical density after 15 days to 25 days of contact, indicates that bacterial cell populations are dying, being unable to survive in extreme environmental situations, due to the presence of organic compounds that are acidic resulting from biodegradation of the bacteria itself, $[5,6,7,17,19]$

\subsection{Time Retention, abundance and new peak formation}

The mechanism of biodegradation of pyrene compounds using bacterial isolates AF, $\mathrm{BS}$ and $\mathrm{BC}$, after 5 days, 10 days and 15 days contact can be seen on chromatogram. 
The appearance of several peaks with different retention times indicates that the formation of organic compounds of bacterial isolates can degrade the pyrene compounds. The abundance of pyrene decreases with the increase of contact time, strengthening the analysis that the pyrene concentration is reduced along with the formation of new peaks which is the presence of new compounds of work on bacterial isolation degradation process. This process occurs in the three types of isolates used as shown in Figures 1, 2, 3, as follows:

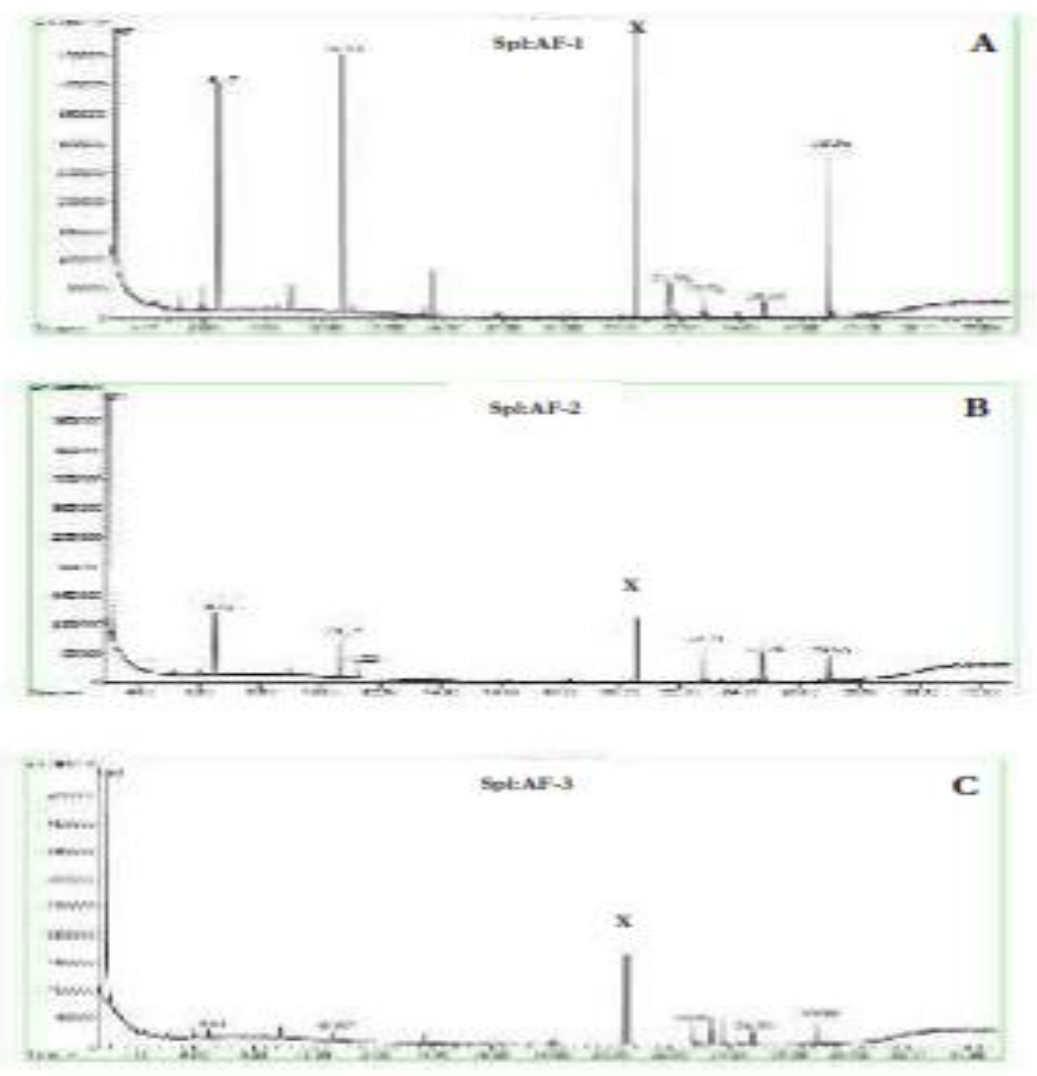

Figure 1. Chromatogram of organic compounds in culture using biodegradator Alcaligenes faecalis strain Cu4-1 (AF), contact time, (A) 5 days, (B) 10 days, (C) 15 days.

Figure 1 above is a biodegradation culture chromatogram between AF isolates and pyrene measured after 5 days of contact (A), 10 days contact (B) and 15 days (C) contact. In the figure shows the abundance of pyrene decreases with increasing contact time, indicating a decrease in pyrene concentration. In chromatogram visible indication of the formation of new compounds characterized by a new peak indicates the presence of new organic compounds due to the degradation of bacterial isolates that reduce the pyrene compound. The work of isolate AF degrades pyrene characterized by the formation of 4 (four) new peaks of different RF values, is the peak of the compound. 

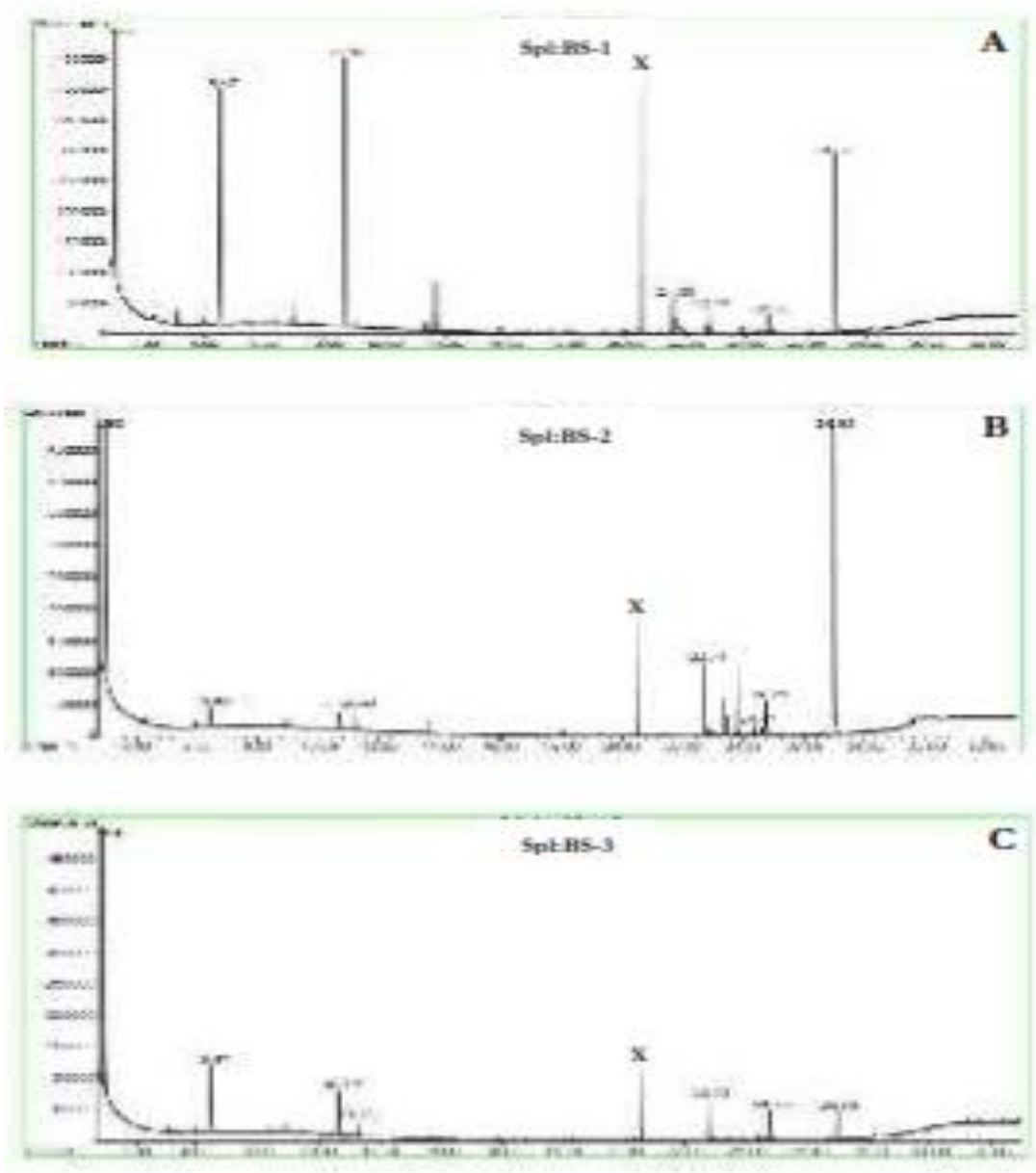

Figure 2. Chromatogram of organic compounds in culture using biodegradator Bacillus subtilis strain BAB-1684 (BS), contact time, (A) 5 days, (B) 10 days, (C) 15 days.

The biodegradation process uses the BS isolate against pyrene, not much different from the AF biodegradation process measured at the same contact time. There are 5 new peaks on the media chromatogram. Newly formed peaks describe there are 5 organic compounds that form the result of biodegradation of $\mathrm{BS}$ isolate to pyrene compound. New types of compounds are reinforced with bleached RF values. Determination of the type of organic compound formed based on GC-MS data library /ID with quality 95 adjusted with retention time and peak area. Differences in the number of peak pyrene biodegradation results by AF compared with BS biodegradation results, indicating that the pathways and biodegradation mechanisms attached by each bacterium in degrading the substrate (pyrene) differ between bacteria with one bacterium. This means that bacteria have specific degradation mechanisms and different from the degradation mechanisms that occur in the use of other types of bacteria 


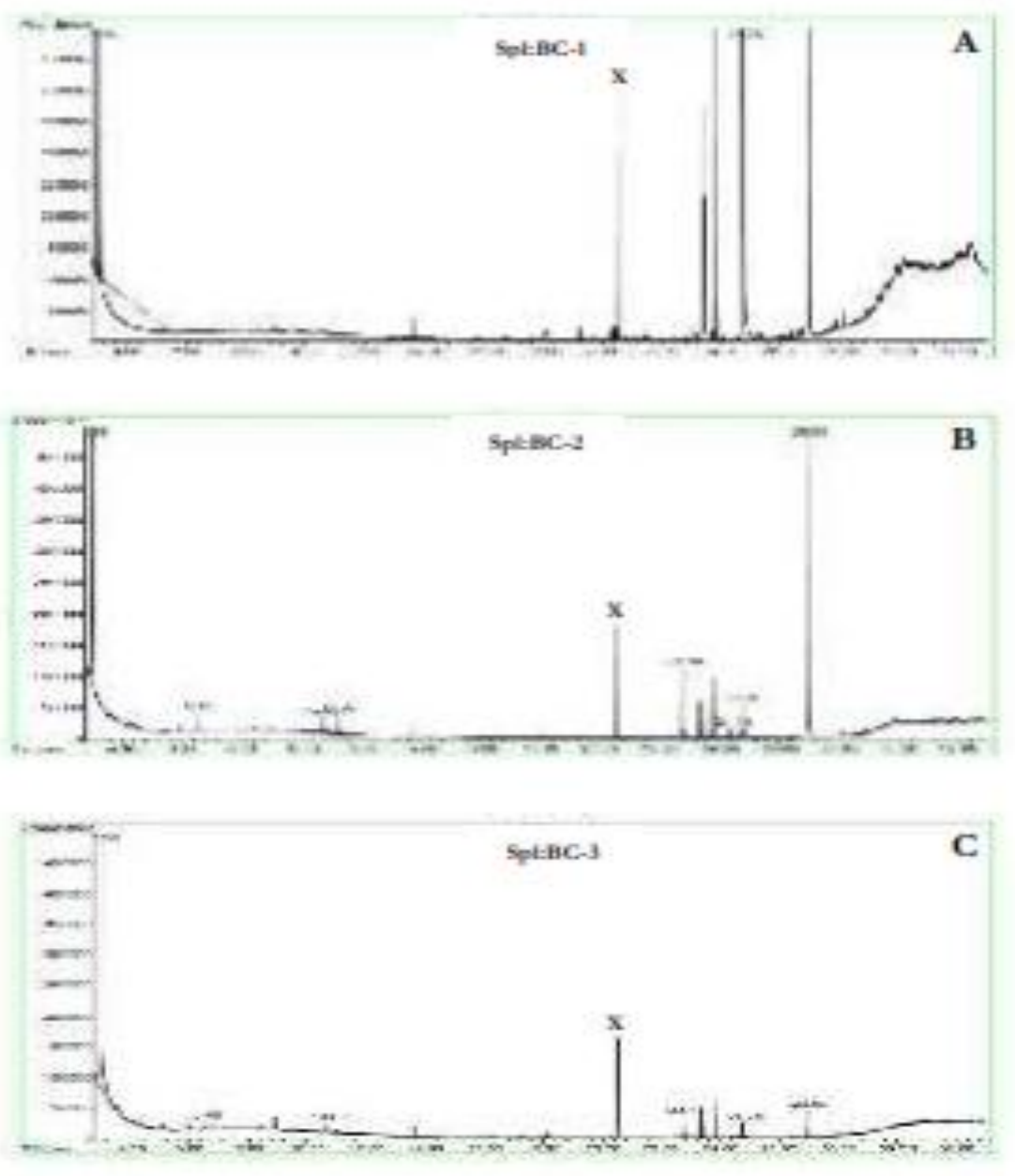

Gambar 3 Kromatogram senyawa organik dalam kultur menggunakan biodegradator Bacillus Cereus strain MER-8 (BC), waktu kontak, (A) 5 hari, (B) 10 hari, dan (c) 15 hari.

Figure 3. Chromatogram of organic compounds in culture using Bacillus Cereus strain MER-8 (BC) biodegradator, contact time, (A) 5 days, (B) 10 days, (C) 15 days.

The mechanism of biodegradation of pyrene by BC isolate, relatively similar with pyrena biodegradation process using $\mathrm{AF}$, but slightly different with biodegradation mechanism using BS, as shown in Figure 3. The similarity of biodegradation mechanism that happened to pyrene using isolate $\mathrm{BC}$ and $\mathrm{AF}$ can be seen at number of new peaks. Which formed a number of 4 pieces and the same retention time each new peak, indicating the type of organic compounds formed from the relatively similar biodegradation results. This is realistic since both isolates (AF and $\mathrm{BC}$ ) are isolated bacteria identified in one seawater sample, whereas the isolate BS is isolated from different sources ie Callyspongia $s p$ of sponge, however it can not be said that the 
biodegradation process that occurs in the PAH compound will be the same if Using bacterial isolates from the same source and different processes if using bacterial isolates from different sources. Characteristics of a bacteria is shown by a strain. If the bacterial strain is different, it shows different bacterial characteristics even though it comes from the same source or even in the same sample. Isolation of bacteria from one type of sample sometimes identified several types of bacteria with different strains, ${ }^{[1,2,5,9,20]}$

\subsection{Changes in Pyrene Concentrations}

The performance of bacterial isolates degrading the pyrene compound was determined by decreasing the concentration of the compound as measured after contact within a few days. The biodegradation rate can be determined by calculating the amount of pyrene compound concentration decrease based on the contact time. The pyrene concentration degraded by bacterial isolates can be seen in Table 2 below:

Table 2. Performance of AF, BS and BC isolates in degrading pyrene compounds measured at 5 days, 10 days and 15 days contact

\begin{tabular}{cccc}
\hline The & $\begin{array}{c}\text { The } \\
\text { concentration of } \\
\text { Pyrene (ppm) }\end{array}$ & $\begin{array}{c}\text { Decrease in pyrene } \\
\text { concentration (ppm) }\end{array}$ & $\begin{array}{c}\text { Level of Degradation } \\
(\%)\end{array}$ \\
\hline Alcaligenes faecalis strain Cu4-1 (AF) & & \\
\hline 0 & 100,09 & 00,00 & 00,00 \\
5 & 68,12 & 31,97 & 31,94 \\
10 & 12,02 & 88,07 & 87,99 \\
15 & 2,35 & 97,74 & 97,65 \\
\hline Bacillus subtilis strain BAB-1684 (BS) & & 00,00 \\
\hline 0 & 100,09 & 00,00 & 24,72 \\
5 & 75,35 & 24,74 & 63,87 \\
10 & 36,16 & 63,93 & 93,15 \\
15 & 6,86 & 93,23 & 00,00 \\
\hline Bacillus Cereus strain MER-8 $(\mathrm{BC})$ & & 40,18 \\
\hline 0 & 100,09 & 00,00 & 91,57 \\
5 & 59,87 & 40,22 & \\
\hline 10 & 28,46 & 71,63 & \\
\hline
\end{tabular}


Based on Table 2, the above shows that the piyene concentration falls as the contact time increases. Significant decrease in pyrene concentration occurs in 5th to 10th day of contact, then an insignificant downward trend occurs in contacts 15 days to 25 days. The trend of decreasing pyrene concentration in degradation media is getting weaker, degradation occurs in the use of three different isolate types, although it is seen that the decrease of pyrene concentration is sharper on the use of isolate AF followed by BC and last BS. This condition has an impact on the level of biodegradation shown by the three types of isolates. The level of biodegradation of isolates to pyrene was measured at the same contact time, successively AF isolates $(97,65 \%), \mathrm{BC}(95,27 \%)$ and BS $(93$, $15 \%$ ). The order of biodegradation rate of bacterial isolates to pyrene has been estimated previously based on trend data of increasing optical density of degradation media. The higher optical density values indicate that more bacterial cells in the media potentially produce enzymes as a threat response to bacterial cells received from extreme environments are contaminated with $\mathrm{PAH},{ }^{[1,2,5,8,10,20]}$

The rate of biodegradation of bacterial isolates against pyrene is influenced by factors: (1) the number of different bacterial cells. The higher the number of possible cells the ability of degradation to hydrocarbons is higher; (2) Acidity of degradation media. Biodegradation results produce acidic organic compounds that can weaken bacterial cells to divide and decrease the ability to enlarge cell size; (3) The ability and speed of bacterial isolates to adapt to extreme polluted media or environment polluted. The performance of bacterial isolates degrading pyrene may differ from one type of isolate to another. The performance of isolates was seen in the degradation rate, ${ }^{[3,6,7,9]}$.

\subsection{Component of biodegradation result in Contact of Media}

The organic compounds identified in the media after contact between bacterial isolates and pyrenes are the result of biodegradability. The type and name of these organic compounds is determined based on the results of chromatogram readings on GC-MS measurements. The name of the selected compound in the library is selected which has a $95 \%$ similarity quality adjusted to the peak number and retention time. Table 3 , the following are the components of identification of organic compounds in culture after contact between isolates of bacteria and pyrene were measured at 15 days of contact. 
Table 3. Components of Organic Compounds identified on biodegradation media of isolates $\mathrm{AF}, \mathrm{BS}$ and $\mathrm{BC}$ after 15 days of contact

\begin{tabular}{lll}
\hline $\begin{array}{l}\text { Component } \\
\text { Number }\end{array}$ & $\begin{array}{l}\text { Retention Time } \\
(\text { RT })\end{array}$ & $\begin{array}{l}\text { The components are } \\
\text { Identified }\end{array}$ \\
\hline Alcaligenes faecalis strain Cu4-1 (AF) \\
\hline $\mathrm{x}$ & 24.76 & pyrene \\
1 & 21,58 & Diphenyl acetylene \\
2 & 11,02 & 1-methyl-4- (1metilenyl) cyclopentane \\
3 & 24,40 & Acid 6-octadecanoate methyl ester \\
4 & 11,22 & 1-methyl-4- (1metilenyl) cyclohexane
\end{tabular}

Bacillus subtilis strain BAB-1684 (BS)

\begin{tabular}{|c|c|c|}
\hline $\mathrm{x}$ & 24.76 & pyrene \\
\hline 1 & 24,48 & Acid. P-methyl-benzoate \\
\hline 2 & 21,58 & Diphenyl acetylene \\
\hline 3 & 11,02 & 1-methyl-4- (1metilenyl) cyclopentane \\
\hline 4 & 24,40 & Acid 6-octadecanoate methyl ester \\
\hline 5 & 11,22 & 1-methyl-4- (1metilenyl) cyclohexane \\
\hline \multicolumn{3}{|c|}{ Bacillus Cereus strain MER-8 (BC) } \\
\hline $\mathrm{x}$ & 24.76 & Pyrene \\
\hline 1 & 21,58 & \multirow{2}{*}{$\begin{array}{l}\text { Diphenyl acetylene 1-methyl-4 (1 methenyenyl) } \\
\text { cyclohexane }\end{array}$} \\
\hline 2 & 11,22 & \\
\hline 3 & 24,40 & Acid 6-octadecanoate methyl ester \\
\hline 4 & 11,22 & 1-methyl-4- (1 ethylethenyl) cyclopentane \\
\hline
\end{tabular}

Table 3, above shows that the components of the organic compounds of pyrene biodegradation identified in the media use bacterial isolates AF, BS and BC. It can be seen that the work of biodegradation of AF bacteria isolate is relatively the same as $\mathrm{BC}$, both on the number of components formed, the component retention time and the type of compound produced, while the organic components of BS isolate biodegradation are slightly different from the results obtained using $\mathrm{AF}$ and $\mathrm{BC}$. The difference is shown in 
the number of new peaks that appear as much as 5 , as well as the types of organic components identified. The identification of p-methyl-bensoate component of the media using bacterial isolate $\mathrm{BS}$, was not found on the use of bacterial isolates $\mathrm{AF}$ and $\mathrm{BC}$. This indicates that the working mechanisms of BS isolates in degrading the pyrene are different from the mechanisms occurring in biodegradation using isolates AA and $\mathrm{BC}$. This difference is rational as the $\mathrm{BS}$ isolate is obtained from sponge isolation of Callyspongia sp. Isolated sources of $\mathrm{AF}$ and $\mathrm{BC}$ isolates derived from bacterial isolation using one seawater sample, ${ }^{[15,17,18]}$

Optical density, retention time to component abundance, Biodegradation rate and pyrene concentration in non-degradable media and the type of organic component of biodegradation results are the variables analyzed to determine the ability of bacterial isolates used in the pyrene component by contact time. The speed of pyrene biodegradation is influenced by the ability of bacterial isolates to reduce the hydrocarbon compound to be used as a carbon source to meet the needs of bacterial energy, so that the life time of bacteria in extreme media contaminated with pear lasts longer, ${ }^{[17,19]}$

\section{CONCLUSION}

Based on optical density parameter, pyrene abundance, biodegradation rate, pyrene concentration and type of degradable organic component, it is concluded that: (1) Three Isolates: Alcaligenes faecalis strain Cu4-1, Bacillus subtilis strain BAB-1684 (BS), Bacillus Cereus MER-8 (BC) strains can degrade pyrene compounds; (2) Order of biodegradation level of bacteria isolate to degradation of pyrene component, ie: AF (97, $65 \%)>\mathrm{BC}(95,27 \%)>\mathrm{BS}(93,15 \%)$; (3) The ability of pyrene degradation by bacteria isolated from seawater is relatively higher than bacteria isolated from Callyspongia sp sponge; (4) The organic component of biodegradation of isolate AF and $\mathrm{BC}$ is different from the organic component of biodegradation result of BS isolate.

\section{REFERENCES}

[1] Gan, S., Lau, E.V., and Ng, H.K., 2009, "Remediation of Soils Contaminated with Polycyclic Aromatic Hydrocarbons (PAHs)", J. Haz. Mat., 172, 532-549

[2] Wu, Y., Teng, Y., Li, Z., Liao, X., and Luo, Y., 2008, "Potential role of polycyclic aromatic hydrocarbons (PAHs) oxidation by fungal laccase in the remediation of an aged contaminated soil”, J. Soil Biol. Biochem., 40, 789-796

[3] Marzuki, I., Noor, A., La Nafie, N., Djide, N., M., 2014, "Isolation and Identification on Degradator Bacterial of Petroleum waste which Symbionts with Sponge Callyspongia sp from Melawai Beach”, Proceeding: International Conference on the sciences (ICOS), Makassar, South Sulawesi, Indonesia, ISBN 
https://scholar.google.co.id/citations?view_op=view_citation\&hl=en\&user=Aj WcdX8AAAJ\&citation_for_view=AjWcdX8AAAAJ:IWHjjKOFINEC

[4] Marzuki, I., Noor, A., La Nafie, N., Djide, N., M., 2015, "Molecular characterization of gene $16 \mathrm{~S}$ rRNA micro symbionts in sponge at Melawai Beach, East Kalimantan”, International Journal Marina Chimica Acta, 16(1), 38-46; https://scholar.google .co.id/citations?view_op=view_citation\&hl=en\&user=AjWcdX8AAAAJ\&citat ion_for_view=AjWcdX8AAAAJ:Wp0gIr-vW9MC

[5] Marzuki, I., Noor, A., La Nafie, N., Djide, N., M., 2015, "Sponge Role In, Alleviating Oil Pollution Through Sludge Reduction, A Preliminary Approach", International Journal of Applied Chemistry (IJAC), 11(4), 427-441, http://www.ripublication.com; https:// scholar.google.co.id/citations view_op=view_citation\&hl=en\&user=AjWcdX 8AAAA J\&citation_for_view=AjWcdX8AAAAJ:qxL8FJ1GzNcC

[6] Udofia, E., 2008, "Rate of biodegradation of crude oil by microorganism isolate from oil sludge environment", African J.Biotechnol.,7, 24

[7] Hadija, E. I., La Nafie, N., Dali, S., 2016, "Isolation and Characterization of Bacteria Degrading Pyrene from Port Paotere, Makassar, South Sulawesi", International Journal Marina Chimica Acta, 17(1), 16-22

[8] Syakti, D. A., Yani, M., Hidayati, V. N., Siregar, S. A. Doumeng, P., and Sudiana, I. M., 2013, “The Bioremediation potential of hydro carbon clastic bacteria isolated from a Mangrove Contaminated by Petroleum Hydrocarbons on the Cilacap Coast, Indonesia", J. Bioremed., 17(1), 11-20

[9] Cai, Quan-Ying, Mo, C., Wu, Q., Zeng, Q., Katsoyiannis, A., and F'erard,J., 2007, "Bioremediation of polycyclic aromatic hydrocarbons (PAHs)contaminated sewage sludge by different composting processes", J. Haz. Mat., $142,535-542$

[10] Okoro, C., and Chuma, 2010, "Application of seawater microbial inocula for the remediation of hydrocarbon polluted mangrove swamp in the Nigerian oil rich Niger Delta”, J. Nat. Sci., 8(8), 152-162

[11] Avecedo, Francisca, Lecticia, Pizzul, Maria, Castilloc, P., Raphael, Cuevas, Maria, and Diez, C., 2011, "Degradation of Polyciclic aromatic hydrocarbons by the Chilean white-rot fungus Anthracophyllum discolor", J. Haz. Mat., 185, 212-219

[12] Tam, N.F.Y and Wong, Y.S., 2008, "Effectiveness of bacterial inoculum and mangrove plants on remediation of sediment contaminated with polycyclic aromatic hydrocarbons", Mar. Poll. Bull., 57, 716-728 
[13] Marzuki, I., 2016, "Sponges Micro symbiont callyspongia sp as Biomaterials Degrading Hydrocarbons", Proceedings of the National Seminar on Chemistry, Lombok-Mataram, Indonesia, ISBN 978-979-8911-97-2， 1，480-450; https://scholar.google.co.id/citations

?view_op=view_citation\&hl=en\&user=AjWcdX8AAAAJ\&citation_for_view= Aj Wcd X8 AAAAJ:4JMBOYKVnBMC

[14] Marzuki, I., Noor, A., La Nafie, N., Djide, N., M., 2015, "The Potential Biodegradation Hydrocarbons of Petroleum Sludge Waste by Cell Biomass Sponge Callyspongia sp”, International Journal Marina Chimica Acta, 16(2):11-20; https://scholar.google .co.id/citations?view_op=view_citation\&hl=en\&user=AjWcdX8AAAAJ\&citat ion_for_view=AjWcdX8AAAAJ:4DMP91E08xMC

[15] Murniasih, T., Yopi, dan Budiawan., 2009. Biodegradasi Fenantren oleh Bakteri Laut Pseudomonas sp KalP3b22 Asal Kumai Kalimantan Tengah. Makara Sains 13(1): 77-80

[16] Teng, Ying, Luo, Y., Sun, M., Liu, Z., Li, Z., and Christie, P., 2010, "Effect of bioaugmentation by paracoccus sp. strain HPD-2 on the soil microbial community and removal of polycyclic aromatic hydrocarbons from an aged contaminated soil”, J. Biores. Technol.,101, 3437-3443

[17] Lin, Y., and Cai, L. X., 2008, "PAH-degrading microbial consortium and its pyrene-degrading plasmids from mangrove sediment samples in Huian", ChinaMar. Poll. Bull., 57, 703-706

[18] White, R. J., Patel, J., Ottesen, A., Arce, G., Blackwelder, P., Lopez, V. J., 2012, "Pyrosequencing of Bacterial Symbionts within Axinellacorrugata Sponges: Diversity and Seasonal Variability", www.plosone.org, e38204, Journal PLoS ONE, 7(6), 1-12

[19] Liu, Z., Shao, Z., 2007, "The diversity of alkane degrading bacteria in the enrichments with deep sea sediment of the South China Sea", J. Wei Sheng Wu Xue Bao., 47, 869-873

[20] Sarbini, K., 2012. Biodegradasi Piren Menggunakan Bacillus Subtilis C19. Fakultas Teknik Program Studi Teknologi Bioproses departemen Teknik Kimia. Universitas Indonesia. Depok 